Jurnal Islamika: Jurnal Ilmu-Ilmu Keislaman

p-ISSN:1693-8712 | e-ISSN: 2502-7565

Vol. 18, No. 01, Juli 2018, pp. 25-38

\title{
HERMENEUTIKA NASR HAMID ABU ZAYD
}

\author{
Muhammad Alfian \\ Institut Agama Islam Negeri (LAIN) Kerinci \\ email: muhammadalfian@gmail.com
}

\begin{abstract}
Islamic studies by taking al-Qur'an as its object have been carried out a lot, using various approaches and methods. One form of the study was carried out by Nasr Hamid Abu Zayd using a hermeneutic approach. In his study, in general Abu Zayd said that the meaning of the Al-Qur'an text cannot be separated from the context of the times in its descent, both of them must have interrelations so that from there, Abu Zayd issued a theory about Ta'wil, Talwin, and Productive Reading
\end{abstract}

Keyword: Islamic studies, Hermeneutic approach 


\section{PENDAHULUAN}

Kebutuhan pengkajian al-Qur`an sudah mulai terasa sejak masa awal sejarah penyebaran Islam dan mencapai respon keilmuan yang cukup penting pada masa Abbasiyah dimana Islam telah menjadi agama bagi orang-orang non Arab, di luar bangsa di mana alQur`an pertama kali diturunkan dan sekaligus pemilik bahasa yang digunakan oleh Tuhan mengartikulasikan firman-firman-Nya. Manna' al-Qaththan menyatakan bahwa sampai masa tadwin (masa kodifikasi keilmuan Islam) telah tumbuh karya-karya tafsir yang berdiri sendiri terlepas dari bidang hadits dengan menafsirkan al-Qur'an sesuai dengan urutan ayat dan surat sebagaimana yang telah tersusun dalam mushaf.

Pembaharuan metodologi tafsir al-Qur`an meniscayakan pergeseran cara pandang terhadap teks al-Qur`an sebagai obyek kajian. Masalah utama dalam studi al-Qur`an adalah mengembalikan kaitan antara kajian al-Qur`an dengan kajian bahasa dan kritik sastra. Antara kajian al-Qur`an dengan sastra tersusun berbagai ilmu yang porosnya satu, yaitu teks, baik teks tersebut berupa al-Qur`an ataupun hadits Nabi. Persoalan tafsir-ta ‘wil sebagai kajian ilmiah terhadap al-Qur an bukanlah tingkat obyektivitas atau subyektifitasnya, namun terhindarkannya dari kecenderungan ideologis, yaitu bias interpreter. Hal inilah yang menjadi pokok pikiran abu zayd, yang akan dijelaskan pada bagian berikutnya.

\section{PEMBAHASAN}

\section{Biografi dan Karya-Karya Nasr Hamid Abu Zaid}

Nasr Hamid Abu Zayd lahir di Desa Qahafah, Tanta, Mesir pada tanggal 19 Juli 1943, mulai dikenal luas kalangan akademisi dan cendikiawan muslim sekitar sepuluh tahun terakhir. Di usia delapan tahun Nasr Hamid Abu Zeid telah hafal Al-qur'an (30 Juz). Diluar pendidikan formalnya ia menulis kitab Mafhumun Nash (Membaca kembali teks) ia menempuh pendidikan SD dikampung halamanya (1951). Setamat dari pendidikan SD ia melanjutkan ke sekolah menengah umum yakni Al-Azhar, namun melihat keinginan yang kuat sang ayah menginginkan anaknya sekolah di kejuruan, guru besar Islamic Studies di Leiden University, dengan masuk sekolah teknologi di distrik Kafru Zayyad, Provinsi Gharbiyah. Setelah itu ia menyelesaikan studi menegahnya, dengan meraih ijazah diploma ( setingkat SMU ) untuk beberapa waktu ia bekerja di sebuah perusahaan kabel (1961-1968) setelah lulus dari Diplomanya. ${ }^{1}$

${ }^{1}$ Nur Ichwan. Meretas Kesarjanaan Kritis al-Qur'an: Teori Hermeneutika Nasr Abu Zaid.,( Teraju: Bandung, 2003), hlm 20 
Pada tahun 1968 Nasr Hamid Abu Zayd melanjutkan ke fakultas Adab, Universitas Kairo. Intensitasnya persentuhanya dengan dunia keilmuan semakin mengkristal dan kuat. Dia tamat di perguruan bergensi ini pada tahun 1972 dengan nilai memuaskan pada masa (S1). Tak menyia-nyiakan kesempatan yang ada, Nasr Hamid Abu Zayd melanjutkan Pasca Sarjana (S2) di universitas yang sama. Di jenjang ini dia menulis tesis berjudul Qadhiyat Al-Majaz fi Al-qur'an Inda Mu’tazilah, pada tahun 1976, juga dengan nilai memuaskan. Pada tahun 1981, dia berhasil meraih gelar doctor dari Universitas Kairo. Nasr Hamid Abu Zayd mengajukan risalah disertai dengan judul Ta'wilu Al-qur'an Inda muhyiddin Al-Araby, dengan nilai memuaskan dengan penghargaan tingkat pertama. Namun ia pernah tinggal di Amerika selama dua tahun (1978-1980), saat memperoleh beasiswa untuk penelitian doktoralnya di Institute of Middle Eastern Studies, University of Pennsylvania, Philadelphia. Karena itu ia menguasai bahasa Inggris lisan maupun tulisan. Ia juga pernah menjadi dosen tamu di Universitas Osaka, Jepang. Di sana ia mengajar bahasa Arab selama empat tahun (Maret 1985-Juli 1989). ${ }^{2}$ Belakangan ia divonis "murtad", dikenal dengan peristiwa "Qadiyyah Nasr Hamid Abu Zayd". "Pemurtadan" Nasr tidak berhenti sampai di situ, tetapi masih terus berlanjut hingga pengadilan banding Kairo menetapkan Nasr harus menceraikan istrinya. Tindakan ini menurutnya sebagai upaya melanggengkan hegemoni kaum Quraysh terhadap kaum muslimin. Semenjak peristiwa itu, dia meninggalkan Mesir dan menetap di Netherlands bersama istrinya. Awalnya, di Netherland Nasr menjadi profesor tamu studi Islam pada Universitas Leiden sejak 26 Juli 1995, hingga 27 Desember 2000 dikukuhkan sebagai Guru Besar Tetap di Universitas tersebut. $^{3}$

Nasr Hamid Abu Zayd merupakan ilmuwan muslim yang sangat produktif, Ia menulis lebih dari dua puluh sembilan (29) karya sejak tahun 1964 sampai 1999, baik berbentuk buku, maupun artikel. Ada sembilan karyanya yang penting dan sudah dipublikasikan, yaitu:

1. The al- Qur'an: God and Man in Communication (Lcidcn, 2000).

2. Al-Khitab wa al-Ta'wil (Dar el-Beida, 2000)

3. Dawair al-Kawf Qira'ah fi al-Khitah al-Mar'ah (Dar el-Beidah, 1999)

4. AI-Nass. al-Sultah, al-Haqiqah: a/-Fikr al-Diniy bayna lrdaat al $\neg$ Ma'rifah wa lradat alHaymanah (Cairo, 1995)

5. AI- Tafkir fi Zaman al- Tafkir: Didda al-.lahl wa al-Zayf wa al $\neg$ Khurafah (Cairo, 1995)

6. Naqd al-Khitab al-Diniy (Cairo, 1994)

7. Mafhum al-Nash: Dirasah fi 'Ulum Alquran (1994) (Cairo, 1994)

${ }^{2}$ Ibid., hlm 21.

${ }^{3}$ Ibid., hlm 194. 
8. Fa/safat a/-Ta'wil: Dirasah fi a/-Ta'wi! al-Qur 'an 'ind Muhyi a/-Din Ibn 'Arabiy (Beirut, 1993)

9. AI-lttijah al-'Aqli fi al-Tafsir: Dirasah Qaqiyyat al-Majaz fi alᄀ-Qur 'an (Beirut, 1982).

\section{Seputar Masalah Teks dan Konteks}

Menurut Abu Zayd, Interpretasi terhadap teks-teks agama (al-Qur'an dan hadis nabi), bagi wacana agama, merupakan salah satu mekanisme yang sangat penting -jika bukan yang terpenting- untuk melontarkan konsep-konsep dan pandangan-pandangannya. Interpretasi yang sejati, yaitu yang menghasilkan makna teks, menuntut pengungkapan makna melalui analisis atas berbagai level konteks. Namun, wacana agama biasanya mengabaikan beberapa level konteks ini, jika tidak mengabaikan keseluruhannya, demi memproteksi pelacakan makna yang telah ditentukan sebelumnya. Pengabaian ini disatu sisi disebabkan tidak disadarinya norma-norma pembentukan teks linguistic, dan di sisi lain disebabkan anggapan bahwa teksteks agama adalah teks yang unik dan berbeda -atau hamper berbeda- sama sekali dengan teks-teks linguistic lainnya. ${ }^{4}$

Bagaimanapun, teks agama tidak terpisah dari struktur budaya tempat ia terbentuk. Sumber ilahi teks tersebut tidak mengesampingkan sama sekali hakikat keberadaannya sebagai teks linguistik dengan segala implikasi kebahasaannya: teks terkait dengan ruang dan waktu dalam pengertian historis dan sosiologis. Teks itu tidak berada diluar kategori bahasa dan memiliki praeksistensi atasnta -yaitu firman tuhan dalam absolusitasnya- sehingga tidak memiliki perangkat epistimologis dan prosedural untuk mengkajinya. Tidaklah demikian adanya, karena dianggap sebaliknya, maka kita tidak dapat memproduksi wacana ilmiah atasnya, dan setiap pembicaraan akan firman tuhan yang berada diluar kerangka bahasa akan menyeret kita, suka atau tak suka, pada wilayah takhayul dan mitos. ${ }^{5}$

Mengingat disini kita dihadapkan pada problematika konteks pembentukan teks maupun produksi maknanya, maka itu hanya memperhatikan beberapa konteks yang terpenting saja. Istilah konteks, walaupun dalam katanya berbentuk tunggal, namun memiliki manifestasi yang beragam. Teks itu sendiri dalam bahasa ilmiahnya beragam, dan lebih beragam lagi jika kita beralih pada teks-teks budaya, yaitu teks dalam artian semiotik. Oleh karena itu, disini cukup disebutkan level-level konteks eksternl (konteks interpersonal), konteks internal (relasi antarunsur), konteks linguistic (komposisi kalimat), dan terakhir konteks pembacaan atau konteks penafsiran. Namun dalam hal ini, hanya aan dibahas pada

\footnotetext{
${ }^{4}$ Nasr Hamid Abu Zayd, teks otoritas kebenaran, terj, (Lkis: Yogyakarta, 2003), hlm. 111

${ }^{5} \mathrm{Hal}$ ini pernah dikaji para pendahulu kita yang melahirkan dua kelompok yaitu mu'tazilah dan asy'ariyah (baca ibid., hlm. 112-114).
} 
sebagian level konteks linguistic yang sangat umum, karna concern kita pada dasarnya berkaitan dengan teks agama dan penentuan level-level kontesny yang diabaikan atau diacuhkan oleh wacana agama dalam berbagai penafsirannya.

Keberadaan firman tuhan yang kudus baru menjadi perhatian hanya pada momen dimana "kalam tersebut diposisikan secara manusiawi" yaitu ketika Muhammad mengujarkannya dalam bahasa Arab. Aspek kultural mengandaikan aspek sosial karena yang terakhir ini mendasari yang pertama, sekalipun yang pertama tetap memiliki kadar kemandirian tertentu dan konteks serta norma-norma yang relative independen darinya. Pada aspek kultural ini mesti dibedakan antara segi epistemologis dan segi ideologis. Epistemologi dalam pengertian kultural adalah kesadaran masyarakat secara umum, terlepas dari perbedaan antar kelompok yang disebabkan perbedaan status sosial mereka. Maka dapat dikatakan bahwa segi epistemology mencerminkan partisipasi dalam proses komunikasi yang terkandung dalam setiap komunikasi kebahasaan, artinya segi inilah yang memungkinkan terjadinya komunikasi dan isi inilah dari mana makna diproduksi. Sementara idelogi adalah kesadaran kelompok yang mempertaruhkan kepentingannya didalam melawan kepentingan kelompok lain dalam suatu masyarakat tertentu, yang bisa dikatakan bahwa ideologi merupakan cerminan urat saraf dari pesan yang terkandung dalam setiap komunikasi kebahasaan dibidang teks, terkecuali teks-teks ilmiah tentunya yang mencoba membongkar pengetahuan yang dominan dengan pengetahuan baru yang terbukti kebenarannya. ${ }^{6}$

Lalu pertanyaannya, mungkinkah memahami teks agama, dan al-Qur'an khususnya, diluar kerangka konteks budaya dan pengetahuan dari kesadaran bangsa arab pada abad VII M. bahasa yang merupakan medium pesan dari teks keagamaan adalah jawaban dari pertanyaan ini, aslkan disadari bahwa ia bukanlah wadah kosong atau semata-mata alat komunikasi yang netral. Akan tetapi, setiap teks memiliki bahasanya sendiri, atau medium sekundernya, didalam system bahasa yang umum. Melalui bahasa sekunder inilah teks-teks agama melontarkan akidah (ideologi) baru, akidah yang pakai teks agama untu merekonstruksi kesadaran pembacanya. ${ }^{7}$

Dalam teks al-Qur'an misalnya, trend kesadaran hanifiyyah sebagai kesadaran yang bertentangan dengan kesadaran paganistik yang dominan dan hegemonic pada saat itu tidak mungin diabaikan. Begitu pula untuk menilai teks al-Qur'an itu sendiri tidak mungkin teks puisi kaum sha'alik diabaikan sebab teks kelompok ini merepresentasikan sebuah upaya menghasilkan teks yang bertentangan dengan teks yang dominan. Hal ini menunjukan bahwa

${ }^{6}$ Ibid., hlm 118-120

${ }^{7}$ Ibid., 122 
teks disatu sisi merupakan hasil kebudayaan. Namun, ia bukan sekedar pantulan reflektif dari struktur budaya, melainkan lebih tepatnya ia turut andil dengan struktur bahasanya yang spesifik -yaitu dengan mekanismenya sendiri sebagai tes- dalam mentransformasikan suatu budaya dari satu tingkat kesadaran ke tingkat kesadaran yang lebih tinggi. ${ }^{8}$

Apabila konteks kultural mencerminkan berbagai hubungan teks dengan realitas eksternal pada berbagai tingatannya, maka konteks eksternal dari teks banyak bersinggungan dan berpotongan dengannya pada berbagai poin. Namun yang membedaan dua level konteks ini adalah bahwa yang terahir mencerminan konteks interpersonal, sebagaimana tampak dalam struktur teks pada kesemua tingkatanny. Konteks interpersonal ini merangkum berbagai tingkat hubungan antara pengujar/pengirim dengan pendengar/penerima, yaitu hubungan yang menentukan keranga penafsiran disisi lain. ${ }^{9}$

Namun konteks eksternal -konteks interpersonal- dalam kasus teks Al-Qur'an tidak ditentukan pada dua aspek terdahulu belaka, yang karena dua itu teks al-Qur'an serupa dengan teks-teks lainnyaa yang tergolong pada bidangnya masing-masing. Selain itu, teks al-Qur'an juga memiliki konteks eksternal yang lebih rumit dari segi sejarah pembentukannya disatu sisi, dan dari segi pergantian karakter yang disapa dari sisi lain. Sebagaimana dimaklumi teks alQur'an merupakan teks yang tersegmentasi (yang terbentuk selama waktu tertentu, dalam hal ini 23 tahun), dan banyak bagian pada saat kemunculannya berkaitan dengan konteks yang dalam wacana agama disebut asbab an-nuzul.dari segi lain, teks itu mengandung tataran wacana yang amat beragam, beragam pula bahasa sekundernya, sebagai akibat dari pergantian situasi yang terjadi pada pihak yang disapa selama masa penurunannya. ${ }^{10}$

Apabila kita beranjak dari konteks eksternal menuju ke kontes internal kita akan langsung memasuki salah satu problem teks al-Qur'an. Konteks internal dalam al-Qur'an memiliki kekhususannya sendiri, yang tercermin dari keberadaan al=Qur'an yang bukan merupakan teks tunggal dan homogen. Disini kita tidak membicarakan persoalan apakah susunannya merupakan ketetapan dari Allah yang mengujarkan teks al-Qur'an, ataukah merupakan ijtihad dari generasi pertama yang menerima teks tersebut secara terpisah-pisah, karena ia merupakan aspek lahiriah disamping pengertiannya dapat mengacaukan kesadaran dalam konteks ajian kita ini yang berupaya mengkajinya secara ilmiah. Terlepas dari hal itu, kajian atas teks kronolpgi menjadi hal yang penting. Para sarjana al-Qur'an telah menangani satu aspek dari kajian ini dalam ilmu yang mereka sebut "ilmu kesesuaian antar ayat dan surat"

\footnotetext{
${ }^{8}$ Ibid.,

${ }^{9}$ Ibid., 123

${ }^{10}$ Ibid., 124
} 
('ilm al-munasabah bain al-ayat wa as-auwar). Namun mereka hanya menunjuan hubunganhubungan rasional, logis atau kebahasaan; sementara hubungan-hubungan semacam ini diakui mereka sendiri sebagai hasil ijtihad yang ditujukan untuk menekankan kebijakan (hikmah) Tuhan dalam urusan semacam ini. ${ }^{11}$

Pluralitas teks dalam teks al-Qur'an ini dalam satu seginya dapat dianggap sebagai produk dari konteks kultural yang menghasilkan teks, sebab ia merefleksikan unsur keserupaan antara teks-teks al-Qur'an dengan teks-teks budaya secara umum dan dengan teks puisi secara khusus. Namun, keserupaan ini pada dirinya mengandung unsur perbedaan, baik dari segi jumlahnya atau rentang waktu yang dihabiskan teks untuk mencapai komposisi finalnya. Ini berarti teks al-Qur'an bertentangan dengan dirinya sendiri secara kontekstual, sebab, konteks internalnya tidak sejalan dengan konteks eksternalnya, atau dengan kata lain konteks saat penciptaan dan konteks strutur internalnya. Disini kita bisa menambahan segi lain, yakni mengenai peran teks al-Qur'an dengan struktur yang demikian didalam menentukan struktur teks bahasa arab pada umumnya. Yang kami maksud adalah gaya sepotong-potong, banyak ragam, perpindahan satu topic ke topik lain sebagaimana dalam karangan prosa berbahasa arab. Namun, persoalan ini memerlukan banyak pengkajian ulang untuk dapat menemukan factor-faktor penyebab mengapa berstruktur semacam itu dan signifikasinya dalam kebudayaan arab. ${ }^{12}$

Analisis level-level linguistik tidaklah cukup berhenti pada unsur-unsur kalimat atau sebatas pada pelampauan makna dari berbagai bentuk (formasi) dan statistika (uslub) saja, tetapi lebih dari itu, analisis berlanjut pada pengungkapan makna "yang terdiamkan" (almaksut 'anhu) dalam struktur wacana. Disini yang dimaksud dengan makna "yang terdiamkan” bukanlah mana yang oleh para ulama ushul fikih sebut sebagai "makna kandungan" (dalalah alfahw) atau "makna pembicaraan" (lahn al-kitab)tetapi yang dimaksud disini adalah level yang lebih dalam lagi yang terungkap dari konteks relasi intelektualitas baik terpisah dari makna eksplisit konteks linguistic. ${ }^{13}$

Dengan demikin konteks linguistic melampaui makna yang tersurat (malfuzh), karena bahasa, bagaimana disebut di bahasan diatas merupakan bagian dari struktur yang lebih luas dari struktur budaya'sosial, dan karenanya, struktur ini tidak menjalankan fungsi komunikatifnya -sebagai struktur makna- kecuali melalui struktur yang lebih luas. Dari sini, kita membatasi makna pada ucapan yang dilafalkan sebagaimana pula kita tidak membatasinya

\footnotetext{
${ }^{11}$ Ibid., 127

${ }^{12}$ Ibid., 128

${ }^{13}$ Ibid., 133
} 
pada makna kandungan, bahkan harus diperluas hingga mencakup wilayah yang didiamkan dalam struktur wacana. ${ }^{14}$

Konteks yang akhir adalah konteks pembacaan. Dalam analisis kita ini, konteks ini tidak terlepas dari level-level konteks sebelumnya. Proses pembacaan-yang pada intinya adalah menguraikan kode- bukan semata-mata konteks eksternal sekunder yang disandarkan pada teks, karena ekspresi teks (encoding) tidak terealisir kecuali melalui aktivitas membaca itu sendiri. Dari sini, pembicaraan mengenai pembaca imajiner struktur teks itu sendiri mendapatkan legitimasinya. Kehadiraan pembaca imajiner tampak lebih jelas dalam teks-teks yang mengarahkan kebenaran pembaca secara mendasar. Diantara teks-teks tersebut yang paling utama adlah teks-teks keagamaan, yang daalam hal ini al-Qur'an. Kehadiran pembaca yang amat mencolok dalam teks al-Qur'an ini dan mendorongnya untuk terus memahaminya, tidak terlepas dari watak pesan pengarah di satu sisi dan watak penutur disisi lain. ${ }^{15}$

\section{Ta'wil, Talwin, dan Pembaacaan Produktif}

Dalam bahasan ini akan dijelaskan mengenai dua konsep yang digunakan dalam pembacaan, yang pertama yaitu ta'wil yang perlu didefinisikan secara cermat maknanya. Pemakaian konsep ta'wil telah bergeser dari wilayah pembacaan atas teks-teks keagamaan dan interpretasi terhadapnya ke wilayah ilmu-ilmu humaniora dan sosiologis, dan dari wilayah yang terakhir ini ke wilayah-wilayah "teori ilmu pengetahuan" (epistemology) dalam filsafat, dan dari sini ke "kritik sastra" dan semiotika". Antara "interpretasi" (ta'wil) dengan "ideologisasi" (takwin) dicampuradukan, dan akhir-akhir ini pembacaan ditekankan pada pentingnya peran pembaca dalam menghadapi konsep, padahal sebelumnya ditujukan pada pentingnya "intensi" pengarang. ${ }^{16}$

\section{Ta'wil: makna bahasa dan istilah}

Dalam sejarah peradaban islam, telah terjadi perselisihan seputar penakwilan dan pemahaman terhadap teks-teks keagamaan. Perselisihan ini mendorong munculnya sejumlah ilmu yang didapat, khususnya, dari teks al-Qur'an, yakni dari pembakuan bacaannya dan dari pemahaman serta penakwilannya, sebagai titik tolak fundamentalnya. ${ }^{17}$

Dari makna bahasa, terdapat dua kontradiksi dari kata ta'wil, yang sebenarnya saling melengkapi. Dimensi pertama tercermin dalam makna dari kata kerja tiga huruf (tsulasi) ala dan deviasi-deviasinya, yang artinya dalah "kembali" (al-'udah dan ar-ruju'). Dari makna ini

${ }^{14}$ Ibid., 134

${ }^{15}$ Ibid., $135-136$

${ }^{16}$ Nasr hamid abu zaid, kritik wacana agama, terj, (Lkis: Yogyakarta, 2003), hlm. 115-116

${ }^{17}$ Diantara ilmu tersebut adalah ilmu-ilmu bahasa, retorika (balaghab), dan ilmu kalam (Nasr Hamid Abu Zaid, teks otoritas), hlm. 137 
kita memahami bahwa ta'wil adalah mengembalikan sesuatu atau fenomena sebagai obyek kajian pada sebab-sebab pertama dan aslinya.dimensi makna kedua dari bentuk kata tiga huruf (tsulasi) ala adalah tindakan yang telah sampai diujung, ujung sesuatu, tujuan akhir. Sebenarnya dua makna ini tidak saling kontradiksi, sebab sampai pada ujung fenomena tidak dapat terwujud apabila melepaskan illat dan sebab-sebab aslinya tidak diketahui. Ta'wil disini adalah realisasi dan sampai pada tujuan, yang dari dua makna ini nyaris merupakan bentuk kata yang kontradiktif, karena hubungan antara kedua maknanya merupakan hubungan sebab akibat. ${ }^{18}$

Ulama al-Qur'an membicarakan makna istilah dari konsep ta'wil biasanya dengan membandingkan makna tersebut dengan makna istilah lainnya, yaitu "tafsir". Meraka mendefinisikan hubungan antara keduanya sebagai hubungan 'amm dan khashs, sebab tafsir menurut mereka merupakan riwayah, sementara ta'wil berkaitan dengan dirayah, ${ }^{19}$ yang dengan kata lain, kata tafsir berkaitan dengan naql, sementara ta'wil berkaitan dengan 'aql. Yang dimaksud dengan naql adalah sejumlah ilmu yang harus dimiliki untuk dapat menembus dunia teks dan untuk dapat membuka katup-katupnya agar sampai pada takwilnya. ${ }^{20}$

Namun demikian, konsep ta'wil tidak terbatas hanya dalam kaitannya dengan teks-teks linguistic semata, lebih dari itu konsep tersebut, mencakup pula, sebagaimana dapat dilihat dengan jelas dari konteks pemakainnya dalam al-Qur'an dan bahasa secara umum, seluruh peristiwa, kejadian dan fenomena. Artinya bahwa konsep tersebut berkaitan dengan bagaimana berintegrasi dengan teks-teks dalam pengertian semiotika secara umum. Tafsir, sebagaimana yang telah dijelaskan berkaitan dengan riwayat dan naql, sementara wilayah ta'wil senantiasa terkait dengan evektivitas akal dan istinbat. Disini harus disadari bahwa wilayah-wilayah epistemology saling bertukar peran sedemikian kompleks sehingga tidak mungkin wilayahwilayah tersebut diklasifikasikan menurut dialektika tafsir/ta'wil. Kalu tidak demikian, kita akan terperrangkap kedalam dikotomi klasifikasi teologis terhadap ilmu. ${ }^{21}$ Objektivitas yang dapat direalisir dalam men-ta'wil-kan teks adalah oblejtifitas kultural yang bergantung pada masa dan tempat, bukan objektifitas mutlak yang sudah pasti hanyalah sekedar "ilusi" hasil dari kreativitas ideologi. Objektivitas kultural dapat terealisir lewat upaya sungguh-sungguh

${ }^{18}$ Nasr Hamid Abu Zaid, kritik wacana agama, hlm. 117

19 Menurut Dr. Amien Abdullah, penggunaan kata tafsir lebih popular dari kata ta'wil. Tafsir menurut amien adalah cara untuk mengurai bahasa, konteks dan pesan-pesan moral yang terkandung dalam teks atau nash kitab suci, disini teks dijadikan "subyek". Sedangkan ta'wil adalah cara untuk memahami teks dan menjadikan teks dengan menjadikan teks dan/atau lebih tepat disebut sebagai pemahaman, disini teks dijadikan "obyek" kajian. (lihat amien Abdullah dkk, tafsir baru studi islam dalam era multikultural, (kurnia kalam semesta: Yogyakarta, 2002), hlm. 1.

${ }^{20}$ Nasr Hamid Abu Zaid, kritik wacana agama, hlm. 118,

${ }^{21}$ Ibid., 119 
pembaca dalam memakai semua sarana analisis melalui "sikap menceburkan diri" kedalam teks dalam upaya menembus kedalamannya. ${ }^{22}$

\section{Talwin (ideologisasi): pembacaan tendensius}

Ketiadaan kebebasan dalam aktivitas secara umum, dan dalam pembacaan teks secara khususnya, secara epistemologis memiliki interpretasinya, sepanjang tindak mengetahui tersebut tidak berangkat dari kekosongan mutlak, menyeluruh, sesuai dengan kondisi kekosongan asal dengan asumsi kondisi kekosongan itu ada. Sementara pembacaan tendesius merupakan kebalikan dari itu. Pembacaan ini selalu berada dalam kerangka ideologis. Sikap ceroboh dalam berinteraksi dengan teks dan dalam menginterpretasikannya biasa terjadi dalam kondisi pengkaji tidak menyadari, atau mengabaikan ideologinya. Hal inilah yang menyebabkan ideologi itu menjalankan perannya secara tersembunyi tanpa pengawasan, tanpa aturan atau kendali. Dalam kondisi seperti ini akan sangat mudah terjadi loncatan dari ta'wil ke takwin, dan batas-batas antara makna dan signifikasi menjadi mencair. ${ }^{23}$

\section{Pembacaan produktif}

Dua sudut yang telah didefinisikan di atas, yang digunakan untuk berinteraksi dengan teks dan memberikan interpretasi terhadapnya tidaklah terpisahkan, meskipun pemisahan antara keduanya merupakan keharusan dari sudut metodologis. Sebenarnya keduanya merupakan dua sisi mata uang. Hal ini karena signifikasi tidak terlepas dari sentuhan makna, sebagaimana signifikasi mengarah (berorientasi) pada dimensi-dimensi makna. Penyingkapan makna mencerminkan upaya kembali ke asal, sementara sampai pada signifikansi mencerminkan tujuan dan sasaran dari tindak pembacaan. Ini berarti ta'wil merupakan gerak bolak-balik antara dua dimensi "asal" dan "tujuan", atau antara "makna" dan "signifikansi" seperti gerak bandul, gerakan tersebut bukanlah satu arah. Tanpa gerak bandul antara signifikansi dan makna, keduanya akan terlihat tercerai berai, dan pembacaan akan semakin menjauh dari interpretasi dan terperangkap kedalam ideologisasi. Dengan kata lain, pembacaan akan bergeser dari pembacaan yang legal, meskipun tidak bebas, ke pembacaan tendensius. Disini perlu ditegaskan bahwa signifikansi yang merupakan titik awal dalam pembacaan bersifat hipotesis-embrional yang dapat diubah, ditolak, atau dipositifkan sesuai dengan makna yang dihasilkan oleh pembacaan. Signifikansi yang mapan atau sudah ditetapkan sebelumnya secara pasti dan beku, hanya akan menjadi hambatan dalam perjalanan menuju pembacaan hlm. 69.

${ }^{22}$ Nasr Hamid Abu Zaid, tekstualitas al-Qur'an: kritik terbadap ulumul Qur'an, terj, (Lkis: Yogyakarta, 2001)

${ }^{23}$ Ibid., 119-122 
yang produktif, yaitu pembacaan yang mengikuti proses, bahkan proses-proses, awal penyingkapan yang dari sini muncul signifikansi hipotesis-embrional yang disebut diatas.

Dialektika makna/signifikansi, atau zahir/batin pada level teks, khususnya teks-teks agung merupakan kenyataan yang takbisa diabaikan. Pembacaan produktif-interpretatif sebenarnya mampu untuk menyingkapnya dan membedakan antara dua kutub dialektika tersebut. Sekarang kita dapat meletakkan dalam kerangka epistemologis sebagian besar teks yang menegaskan pluralitas level makna dalam teks-teks keagamaan khususnya, dengan syarat kita menggeneralisasikan konsep tersebur agar mencakup teks-teks non keagamaan disatu sisi, dan mendasarkan pluralitas tersebut pada hubungan dialektis antar level-level makna disisi lain. $^{24}$

\section{Kritik Atas Teori Hermeneutika Nasr Hamid Abu Zaid}

Penggunaan hermeneutika yang menghasilkan asumsi historisitas Al-quran dengan dalih bahwa perbuatan Tuhan bila telah teraktualisasi dalam sejarah, maka harus tunduk pada peraturan sejarah, sejatinya telah menimbulkan konsekwensi yang rumit untuk diterima akal sehat. Apakah dengan demikian Tuhan tunduk mengikuti kaedah peraturan alam yang diciptakan-Nya sendiri? Apakah kemudian wahyu dapat "diseret" untuk mengikuti kemauan realitas sejarah yang berkembang? Karenanya menurut Adian Husaini, ${ }^{25}$ konsep Alquran yang diuraikan Nasr Hamid Abu Zayd di atas bukan hanya bertentangan dengan pengertian Alquran yang dikenal oleh umat, namun telah membubarkan konsep wahyu dalam Islam. Sebab dengan corak pemahaman ala Abu Zayd bahwa kemutlakan Alquran dan sakralitasnya telah sirna dan menjadi teks manusia ketika masuk dalam pemahaman Nabi, diaplikasikan dalam kehidupan dan disampaikan kepada umatnya, akan membatalkan konsep wahyu yang dikenal dalam Islam. Semua umat Islam sepakat bahwa pengertian Alquran adalah Firman Allah yang diwahyukan kepada Nabi Muhammad SAW secara lafzhan wa ma'nan (lafazh dan maknanya) dengan perantara Jibril AS, terjaga dalam mushaf, kemudian disampaikan kepada para Sahabat dan diwariskan dari generasi ke generasi secara mutawatir (recurrence) tanpa keraguan sedikitpun. Membacanya adalah ibadah, di dalamnya terkandung berbagai mukjizat, petunjuk dan ilmu pengetahuan. Sedangkan dalam dataran epistemologis (epistemic level), Abu Zayd dan kelompok modernis lainnya yang menerapkan metode historis (historical methodology), baik dinyatakan secara eksplisit atau tidak, sebenarnya telah menolak sumber

24 Ibid., 124-125.

25 Adian Husaini, Hermeneutika Pemikir Kontemporer: Kasus Nasr Hamid Abu Zayd \& Mohammad Abid al-Jabiri, http:// pondokshabran. org/ index. php? Itemid= 17\&id $=32 \& o p t i o n=$ com $_{-}$content \&task=view, 2005), hlm. 4 
ketuhanan (the divine source) terhadap Alquran yang mereka anggap sebagai realitas holistik (the holistic reality) yang dihasilkan dari metodologi penelitian ilmu-ilmu sains. Pernyataan Abu Zayd bahwa Alquran adalah produk budaya, fenomena sejarah dan teks linguistik membawa pengertian bahwa Alquran dihasilkan secara kolektif dari serangkaian faktor politik, ekonomi dan sosial. Atau dengan kata lain, Alquran adalah hasil pengalaman individual yang diperoleh Nabi Muhammad dalam waktu dan tempat tertentu (specific time-space context), dimana latar belakang sejarah saat itu mengambil peranan inti dalam mewarnai pemikiran beliau dan bahasa sebagai perangkat ungkapan sejarah (expressional tool of history). Dengan demikian, memahami agama dengan cara menundukkannya dalam ruang sejarah, bahasa dan budaya yang terbatas adalah watak dasar hermeneutika yang dikembangkan oleh peradaban Barat yang tidak sejalan dengan Islam.

Sebagai pembaca yang menjadi hakim dalam memaknai teks, Nasr Hamid Abu Zayd menganjurkan untuk mengunci firman Tuhan dalam ruang dan waktu. Kemudian membatasi makna Alquran menurut zaman tertentu dalam sejarah. Dengan cara ini, pembaca teks dapat memahami teks secara ilmiah dan tidak kaku serta terpaku, baik oleh pandangan dogmatissektarian (madzhab minded), permasalahan ideologis (iman-kufur), mistis, tabu (desakralisasi) maupun khurafat. Sebaliknya, dalam pandangan Nasr Hamid Abu Zayd, corak pendekatan ulama klasik dalam pembacaan teks, terikat dengan pendekatan asbab al-nuzul dan naskh wa mansukh adalah terpaku dan tidak ilmiah. Sebab meskipun kedua pendekatan ini juga memperhatikan data empiris, namun pada kenyataannya data empiris yang ditampilkan tersebut masih diwarnai oleh peran Pencipta Teks. Dengan demikian, kecenderungan ulama klasik yang lebih memposisikan teks agama sebagai hakim daripada akal, dipandangnya sebagai corak pendekatan ideologis. Kecenderungan Abu Zayd yang lebih mengesampingkan Sang Pembuat Teks (tidak terlalu tersentuh oleh bahasan abu zayd), kemudian menjadikan pembaca teks dengan segala kondisi sosial, politik dan budaya yang melatarbelakanginya, sebagai hakim yang menentukan arah pemaknaan teks, sebenarnya adalah bentuk pengutamaannya terhadap realitas lahiriyah (al-waqi` al-madi, material reality). Sebab baginya, segala aktivitas berfikir yang selalu terbayang-bayangi oleh realitas ketuhanan dan metafisika (akidah, pahala, siksa, syari'ah dan akherat) dipandang sebagai bagian dari mitos (usthurah). Maka dengan demikian Abu Zayd lebih mengutamakan realitas (al-waqi') daripada pikiran. Dan baginya, teks adalah hasil dari sebuah realitas. Maka setiap perubahan yang terjadi dalam realitas, menuntut perubahan dalam pembacaan teks, sampai akhirnya terjadi kesepaduan antara teks dan realitas (zaman dan 
tuntutannya). ${ }^{26}$ Sehingga menurut Hendri Sholahuddin, ${ }^{27}$ tujuan teori tafsir Nasr Hamid Abu Zayd yang ingin menghilangkan ideologi sektarian, justru sangat rancu. Sebab unsur ideologi dalam suatu penafsiran tidak bisa dinetralisir. Ibarat dua sisi mata uang, mengesampingkan suatu ideologi hanya akan terjebak dalam ideologi lainnya. Dengan kata lain, menolak suatu ideologi adalah ideologi itu sendiri, seperti halnya menolak kemapanan adalah menetapkan ketidakmapanan atau bentuk lain dari sebuah kemapanan.

Terlepas dari semua kritikan diatas, sosok serta pemikiran Nasr Hamid Abu Zayd sesungguhnya telah melahirkan ijtihad baru dalam metode penafsiran. Sebagai sebuah teori, tentu harus tetap terus diuji kebenarannya, Sehingga pada akhirnya yang diikuti oleh umat (utamanya yang awam) tetunya teori yang telah teruji dan dapat dipertahankan.

\section{PENUTUP}

Menurut pandangan abu zayd, interpretasi terhadap teks agama tidak terlepas dari dimensi budaya tempat dimana teks agama ini diturunkan. Bisa dikatakan bahwa untuk memahami teks agama, kita tidak bisa mengklaim bahwa teks tersebut sudah berbentuk dan berbahasa seperti itu dari awalnya (dari Tuhan), namun terbentuk dan tertata sesuai dengan kultur budaya arab, yang oleh karenanya, ada beberapa level konteks yang harus dibahas agar bisa benar-benar menemukan kebenaran dalam interpretasi ini, yaitu antara lain: level-level konteks eksternl (konteks interpersonal), konteks internal (relasi antarunsur), konteks linguistic (komposisi kalimat), dan terakhir konteks pembacaan atau konteks penafsiran.

Dalam melakukan pembacaan pada teks agama, serta untuk meng interpretasikannya, abu zayd lebih menekankan pada metode ta'wil, yang dimana metode ini tidak sekedar melakukan penafsiran pada teks sesuai dengan kata perkatanya saja. Ta'wil disini adalah realisasi dan sampai pada tujuan, yang dari dua makna ini nyaris merupakan bentuk kata yang kontradiktif, karena hubungan antara kedua maknanya merupakan hubungan sebab akibat. Objektivitas yang dapat direalisir dalam men-ta'wil-kan teks adalah oblejtifitas kultural yang bergantung pada masa dan tempat, bukan objektifitas mutlak yang sudah pasti hanyalah sekedar "ilusi” hasil dari kreativitas ideologi.

26 http://www.hermeneutika studi ataspemikiran nasr hamid abu zaid_yayasan islam abuthalib.htm diakses pada: 3 oktober, 2013

${ }^{27}$ Hendri Sholahudin, Al-Qur'an dan Teori Hermeneutika Nasr Hamid Abu Zayd, (http://www. Ppmi pakistan. or.id/?p=20, 2009), hlm. 12. 


\section{REFERENSI}

Abdullah, Amien dkk, tafsir baru studi islam dalam era multikultural, kurnia kalam semesta: Yogyakarta, 2002),

http://www.hermeneutika studi atas pemikiran nasr hamid abu zaid_yayasan islam abuthalib.htm diakses pada: 3 oktober, 2013

Ichwan, Nur. Meretas Kesarjanaan Kritis al-Qur'an: Teori Hermeneutika Nasr Abu Zaid., Teraju: Bandung, 2003

Sholahudin, Hendri, Al-Qur'an dan Teori Hermeneutika Nasr Hamid Abu Zayd, (http://www. Ppmi pakistan. or.id/?p=20, 2009

Zaid, Nasr Hamid Abu, kritik wacana agama, terj, Lkis: Yogyakarta, 2003 teks otoritas kebenaran, terj, Lkis: Yogyakarta, 2003 tekstualitas al-Qur'an: kritik terhadap ulumul Qur'an, terj, Lkis: Yogyakarta, 2001 